\title{
Marta Wesołowska
}

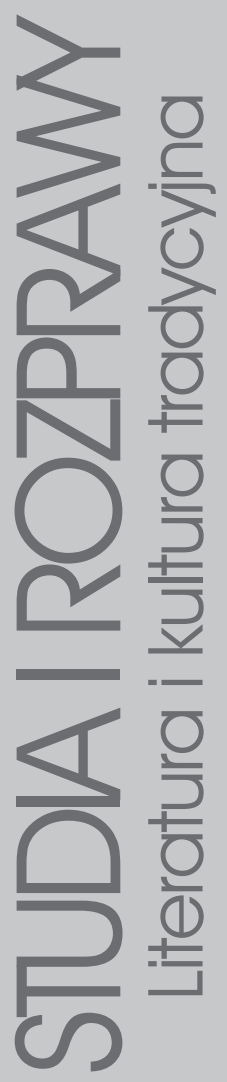

Marta Wesołowska - japonistka specjalizująca się w badaniu muzyki i literatury japońskiej okresu Heian (IX-XII w.). Studia japonistyczne ukończyła w 2008 roku na Uniwersytecie im. Adama Mickiewicza w Poznaniu, gdzie obecnie pracuje jako wykładowca. W Wydawnictwie Trio opublikowała książkę Gagaku. Dzieje i symbolika japońskiej muzyki dworskiej (Warszawa 2012). 


\section{Muzyka w Makura no sōshi}

DOI: http://dx.doi.org/10.12775/LC.2014.020

najstarszej literaturze europejskiej (X-XII w.) znaleźć można wiele opisów muzyki, która jest przedstawiana zarówno jako rozrywka umilająca życie bohaterów utworów, jak i jako potężna siła o tajemnych właściwościach, umożliwiająca przeciwstawianie się złym mocom, zwyciężanie choćby najgroźniejszego przeciwnika w boju czy zmienianie biegu historii. W pełnej zaciekłych walk i przemocy Europie muzyka nabrała zatem magiczno-symbolicznego znaczenia. Dostrzeżono jej dynamikę i moc znacznie wykraczającą poza funkcję zwykłej rozrywki i zaczęto traktować ją jako narzędzie walki, wykorzystywać do zagrzewania do boju czy jako niezbędny element praktyk religijnych.

Zgoła inny obraz muzyki wyłania się z kart japońskiej literatury tego samego okresu (X-XII w.), ponieważ powstawała ona w czasie, kiedy w kraju panował względny pokój, a żyjący w zbytku arystokraci dworu w Heian-kyō (Miasto Pokoju i Spokoju; obecne Kioto) beztrosko oddawali się rozrywkom artystyczno-literackim i przyczyniali się do spektakularnego rozkwitu rodzimej kultury. W niniejszym artykule przedstawiono problem opisu muzyki w dziele Makura no sōshi Sei Shōnagon (966-1017).

\section{Makura no sōshi - tło historyczne}

Makura no sōshi (Zapiski spod wezgłowia; lub Zeszyt spod wezgłowia) napisana przez damę dworu, Sei Shōnagon, to, obok Genji monogatari (Opowieść o księciu Genji, 1008) ${ }^{1}$ Murasaki Shikibu (978-ok. 1016), drugie arcydzieło jedenastowiecznej literatury, ukazujące życie arystokracji dworu Heian. Zapiski spod wezgtowia powstawały w latach 993-1000, kiedy ich autorka pełniła służbę na dworze cesarzowej Teishi (977-1001), żony cesarza Ichijō (980-1011). Życie w pałacu, panujące tam stosunki międzyludzkie dostarczyły Sei Shōnagon inspiracji do stworzenia pamiętnika, który dziś jest uznawany za jedno z najważniejszych utworów w dziejach literatury japońskiej.

* Niniejszy tekst stanowi fragment pracy doktorskiej autorki, zatytułowanej Muzyka i muzyczność prozy japońskiej okresu Heian.

1 Genji monogatari - najsłynniejsze dzieło literatury japońskiej okresu Heian; zawiera 54 zwoje (księgi), w których najpierw (42 księgi) zostały opisane opisuje losy tytułowego bohatera, jego przygody miłosne, duchowe, zawodowe, a następnie dzieje jego potomków. Dzieło jest cennym źródłem wiedzy na temat życia i kultury arystokracji Heian. 
Powstanie utworu przypada na okres Heian (794-1185), czyli na czasy największego rozkwitu kultury dworskiej. W wyniku zerwania stosunków dyplomatycznych z Chinami w drugiej połowie IX wieku, wolny od wpływów kontynentalnych kraj zaczął rozwijać się w izolacji, dając początek unikalnej kulturze. Ton nadawali jej przede wszystkim panujący wówczas arystokraci z rodu Fujiwara. Dzięki temu, że byli oni znacznie bardziej zaangażowani w dworskie rozrywki niż w rządzenie państwem, przyczynili się do rozwoju sztuki, głównie malarstwa, literatury i muzyki, które oddziaływały na siebie z wielką siłą, ponieważ właśnie w okresie Heian nastąpił intensywny rozwkit form muzycznych sprowadzanych do Japonii od V wieku z Chin i Półwyspu Koreańskiego. Ich połączenie z rodzimą tradycją dało początek dworskiej muzyce gagaku², wykonywanym do niej tańcom bugaku czy inspirowanym również muzyką kontynentalną popularnym pieśniom ryūkōka. Muzyka gagaku, która jeszcze w VII wieku miała przede wszystkim charakter rytualny i służyła jako oprawa muzyczna ceremonii shintoistycznych oraz buddyjskich, w IX wieku zaczęła odgrywać rolę rozrywki uprzyjemniającej życie arystokracji dworskiej. Fascynacja popularnymi formami muzycznymi, a także waga, jaką przywiązywano do umiejętności gry na instrumencie, znalazła odzwierciedlenie w ówczesnej literaturze, a zwłaszcza w monumentalnej Opowieści o księciu Genji, w Utsubo monogatari (Opowieść o dziupli, XI w.) nieznanego autora i w Zapiskach spod wezgtowia. Z utworów tych dowiadujemy się, że umiejętność gry na instrumencie stanowiła świadectwo wysokiego statusu społecznego, a warunkiem uznania dla każdej szanującej się damy było opanownie sztuki kaligrafii, gry na cytrze $k$ koto $^{4}$ oraz znajomość poezji z cesarskiej antologii Kokinwakashū (Zbiór pieśni dawnych i dzisiejszych, 905) $)^{5}$. Dlatego tematykę muzyczną podejmowano w literaturze znacznie częściej niż w Europie. Dzięki temu wiele japońskich utworów tego okresu nie tylko stanowi dziś cenne źródło wiedzy na temat życia muzycznego tamtych czasów, lecz także dostarczają nam one wiedzy i o postrzeganiu dźwięku, i o wielkiej wrażliwości na muzykę i słowo. Intensyfikują ponadto estetyczne doznania czytelnika i wpływają na wzbogacenie wartości artystycznej danego dzieła literackiego. Na wielu jego kartach znaleźć można plastyczne opisy wzajemnego oddziaływania muzyki i literatury w okresie Heian, na podstawie których bez trudu można sobie wyobrazić, jak wielką wrażliwością i wiedzą muzyczną odznaczali się ówcześni arystokraci dworscy, a także jak istotny wpływ miała muzyka na kształtowanie stylu literackiego, którego dominującymi cechami stały się poetyckość, rytmiczność, aluzyjność, ascetyczność formy.

Atutem Zapisków spod wezgłowia jest unikalny eseistyczno-pamiętnikarski styl bez trudu rozpoznawalny po zapisie pozbawionych ciągu przyczynowo-skutkowego luźnych myśli i spostrzeżeń autorki. W taki niezwykły sposób wprowadza ona czytelnika w wysublimo-

\footnotetext{
2 Szerzej na temat gagaku zob. M. Wesołowska, Gagaku. Dzieje i symbolika japońskiej muzyki dworskiej, Warszawa 2012.

${ }^{3}$ Bugaku - rytualne tańce z towarzyszeniem muzyki gagaku. Wywodzą się od rozmaitych form muzyczno-tanecznych importowanych z Chin, Indii, Korei i Wietnamu. Szerzej na temat bugaku zob. E. Żeromska, Maska na japońskiej scenie. Od pradziejów do powstania teatru nō, Warszawa 2003.

${ }^{4}$ Koto - rodzaj cytry japońskiej o długości ok.180 cm i trzynastu jedwabnych strunach, szarpanych za pomocą trzech plektronów nakładanych na palce.

${ }^{5}$ Kokinwakashū (Zbiór pieśni dawnych i dzisiejszych), w skrócie Kokinshū - najstarsza antologia poezji japońskiej (waka) skompilowana w 905 roku z rozkazu cesarza Daigo (897-930). Spisana w dwudziestu zwojach, obejmuje 1111 poematów oraz przedmowę autorstwa głównego redaktora Ki no Tsurayukiego (ok. 868-945) i posłowie Ki no Yoshimichiego (?-919).
} 
wany świat arystokracji dworskiej XI wieku. Opisuje różne aspekty życia na dworze i panujących tam obyczajów. Robi to w niezwykle subiektywny sposób, analizując zachowania wybranych postaci i zdradzając zarazem własne, często krytyczne poglądy na temat ludzkiej natury czy stosunków społecznych. Zapiski spod wezgłowia zwracają uwagę głównie tym, że Sei Shōnagon poświęciła w nich szczególnie dużo miejsca muzyce. Opisała nie tylko popularne wówczas pieśni i tańce dworskie, ale również osobiste reakcje na dźwięki zwykle niesłyszane, bądź ignorowane przez przeciętnego melomana. Dźwięki piskliwe, jak i subtelne głosy przyrody towarzyszące nam w codziennym życiu.

\section{Makura no sōshi jako obiekt badań muzykologicznych}

Wiarygodność opisów muzycznych zawartych w Zapiskach spod wezgłowia została jednak podważona przez większość muzykologów i literturoznawców, którzy zarzucają Sei Shōnagon głównie amatorstwo ocen oraz - jak twierdzą - nieumiejętność gry na jakimkolwiek instrumencie. Tego właśnie próbuje dowieść między innymi Kuboki Tetsuo w swojej książce Shōnagon wa koto ga hikenakatta (Shōnagon nie umiała grać na koto, 1960). Analizuje w niej wybrane opracowania i tłumaczenia Zapisków spod wezgłowia na współczesny język japoński oraz zwraca uwagę na to, że autorka, nigdy nie nauczywszy się grać na żadnym instrumencie, szczerze zazdrościła innym dworzanom, że pobierali lekcje gry. Przytaczane przez Kubokiego argumenty okazały się na tyle przekonujące, że wielu badaczy wyżej ceniło Genji monogatari, w którym można znaleźć dużo skrupulatnych opisów form muzycznych, tańców, instrumentów czy skal. Na podstawie tych informacji możliwe okazało się nawet precyzyjne odtworzenie starożytnej muzyki. Świadczy to niezbicie o tym, że wiedza muzykologiczna Murasaki Shikibu - obdarzonej niepospolitym talentem literackim solistki cytry koto - daleko wykraczała poza horyzont poznawczy przeciętnych dworzan.

Pierwszą osobą, która podjęła się próby analizy wszystkich fragmentów muzycznych występujących w Opowieści o księciu Genji i ustalenia obrazu życia muzycznego na dworze w okresie Heian, był Yamada Yoshio (1875-1958). W swojej pracy Genji monogatari no ongaku (Muzyka Genji monogatari, 1934) przedstawił on wyłonione przez siebie z tekstu utworu zdania i terminy dotyczące zarówno urzędów związanych z muzykąa ${ }^{6}$ jak i teorii muzycznej, instrumentów, widowiska bugaku oraz muzyki instrumentalnej kangen ${ }^{7}$, a następnie zestawil i porównał $\mathrm{z}$ terminologią użytą $\mathrm{w}$ dwóch specjalistycznych rozprawach: Kyōkunshō (Zbiór nauk, 1233), której autorem jest Koma no Chikazane (1177-1242) oraz Gakkaroku (Kronika rodów muzycznych, 1690) Abe Suehisy (1622-1708). Dzięki temu Yamada zdołał skonfrontować znaczenia różnych terminów oraz porównać stan świadomości muzycznej arystokratów dworskich okresu Heian. Jego praca została wprawdzie wysoko

\footnotetext{
${ }^{6}$ W okresie Nara (710-794) powstaje urząd muzyki gagaku (Gagakuryō), który w następnym stuleciu zostaje przemianowany na Gakuso - Wydział Muzyki.

7 Kangen - gatunek muzyki dworskiej gagaku; muzyka instrumentalna przeznaczona na orkiestrę zbudowaną z trzech instrumentów dętych (flet ryūteki, obój hichiriki, organki shō), dwóch strunowych (cytra gakusō i lutnia biwa) oraz trzech perkusyjnych (bębny taiko i kakko, oraz gong shōko).
} 
oceniona, ale jest on krytykowany za to, że opierając swą publikację głównie na Kronice rodów muzycznych, odtworzył jedynie muzykę gagaku czasów nowożytnych (1600-1868), natomiast nie określił, jakie było gagaku w okresach wcześniejszych (Heian).

W 1997 roku powstała obszerna monografia zatytułowana Genji monogatari jidai no ongaku kenkyū (Analiza muzyki z czasów Genji monogatari), której autorka, Iso Mizue, porównując opisy muzyczne zawarte w Opowieści o księciu Genji oraz Zapiskach spod wezgłowia, dowiodła, że w każdym z tych utworów przedstawiono dwa nieco odmienne style gagaku (odpowiednio): nara (z Nary) i kyō (z Kioto). Odkrycie to okazało się przełomowe, ponieważ wcześniej nie zdawano sobie sprawy z istnienia jakichkolwiek różnic w prezentowaniu gagaku w zależności od ośrodka muzycznego. W książce Iso znaleźć można ponadto analizę zgodności opisów zawartych w dziełach literackich z powstałymi w X i XI wieku. opracowaniami muzykologicznymi, a także szeroki dyskurs poświęcony roli solmizacji shōga ${ }^{8} \mathrm{w}$ życiu muzycznym okresu Heian oraz poezji (ei), śpiewanej podczas prezentowania widowiska bugaku. Analiza muzyki z czasów Opowieści o księciu Genji ma zatem przede wszystkim wartość historyczną i muzykologiczną. Nie można natomiast znaleźć w niej odpowiedzi na pytanie, w jaki sposób muzyka funkcjonowała w literaturze okresu Heian, ani dowiedzieć się, co i jak pisała o muzyce Sei Shōnagon w Zapiskach spod wezgłowia (poza jedną wzmianką na temat stylu naragata $)^{9}$.

Jedynej próby analizy opisów muzyki w Zapiskach spod wezgłowia dokonała Motegi Kyōko, która w książce Makura no sōshi no kijutsu ni arawasareta nihonjin no oto e no shisei (Stosunek Japończyków do dźwięku odzwierciedlony w tekście Makura no sōshi, 1987) podjęła się naukowego opracowania muzyki oraz sposobu recepcji dźwięku przez Japończyków. Autorka - wyłoniwszy z tekstu Sei Shōnagon opisy wszystkich rodzajów dźwięków (między innymi muzyki wykonywanej podczas ceremonii shintoistycznych i buddyjskich, dźwięków poszczególnych instrumentów, powozów czy odgłosów ze świata przyrody) oraz po przeanalizowaniu kontekstu, w jakim występują one w utworze - stara się dociec, jak na przestrzeni dziejów zmieniała się wrażliwość Japończyków na dźwięki. Motegi odwołała się również do prac z zakresu neuropsychologii i audiologii, a zwłaszcza do wyników badań Tsunody Tadanobu, który w swym kluczowym dziele Nihonjin no nō - nō no hataraki to seiyō no bunka (Mózg Japończyków - jego praca a kultura Zachodu) dowiódl, że różnice między Europejczykami i Japończykami wynikają w istotnym stopniu z ich zasadniczo odmiennej recepcji dźwięków. Tsunoda odkry1, że Europejczycy kojarzą dźwięk z brzmieniem, wysokością tonu, a z punktu widzenia fizyki - z falą dźwiękową, podczas gdy „wszystkie inne odgłosy określają między innymi jako hałas bądź antydźwięk”10. Japończycy natomiast desygnują jako dźwięk każde uderzenie w bęben, otarcie plektronem czy nawet oddech grajacego na flecie. Ponadto muzykę przyrody odbierają oni nie prawą (jak ludzie Zachodu), ale lewą półkulą mózgu odpowiedzialną za recepcję języka, co wyjaśniałoby istnienie tak wielu wyrazów onomatopeicznych w strukturze języka japońskiego ${ }^{11}$.

8 Shōga-japoński solfeż służący do nauki śpiewu i zapamiętania linii melodycznej granej na instrumencie. Jest to pierwszy etap nauki gry na instrumentach wchodzących w skład orkiestry gagaku.

9 Terminem naragata określa autorka styl gagaku prezentowany w świątyni Kasuga-taisha w Narze. Iso Mizue wylicza różnice w liczbie muzyków, obsadzie orkiestry i sposobie wykonywania tańców podczas koncertu gagaku w Narze i Kioto.

${ }^{10}$ K. Motegi, Makura no Sōshi no kijutsu ni arawasareta nihonjin no oto he no shisei, "Bulletin of Joetsu University of Education" 1987, vol. 6, no. 3, s. 215.

11 Mózg każdego człowieka podzielony jest na prawą i lewą półkulę. Półkula lewa zwana werbalną, jest odpowiedzialna za funkcje językowe, matematyczne i logiczne, prawa zaś nazywana kreatywną i muzyczną, 
Praca Motegi stanowi zatem analizę kulturowej recepcji dźwięku przez Japończyków i, pomimo że podejmuje temat muzyczności w dziele literackim, jej celem jest przede wszystkim ukazanie specyfiki i źródła japońskiej wrażliwości na dźwięki. W niniejszym artykule pragnę natomiast przedstawić problem związków muzyczno-literackich i na podstawie wniosków płynących z uważnego prześledzenia kontekstu występowania opisów muzycznych w Zapiskach spod wezgłowia spróbować określić rolę muzyki w literaturze japońskiej okresu Heian.

\section{Zapiski spod wezgłowia - okoliczności powstania dzieła}

Niewiele pozostało do dziś informacji na temat życia Sei Shōnagon i jej zainteresowań muzycznych. Wiadomo jednak na pewno, że ta utalentowana autorka była córką znanego uczonego i poety o nazwisku Kiyohara no Motosuke (908-990), natomiast jej dziadek, Kiyohara no Fukayabu (lata życia nieznane), zasłynął zarówno jako wirtuoz cytry koto, jak i mistrz krótkiej formy poetyckiej waka ${ }^{12}$. Z Zapisków spod wezgłowia dowiadujemy się, że w wieku dwudziestu siedmiu lat Sei Shōnagon rozpoczęła służbę na dworze młodziutkiej cesarzowej Teishi - żony cesarza Ichijō, córki Fujiwara no Michitaki (953-995).

Z Zapisków Sei Shōnagon wypływa wprawdzie wiele radości i humoru, ale rzeczywistość dworska wcale nie napawała jej optymizmem. Kiedy w 995 r. umiera Fujiwara no Michitaka, prestiż cesarzowej Teishi zaczyna słabnąć i rozpoczyna się walka o władzę między synem Michitaki, Fujiwara no Korechiką (974-1010), a jego młodszym bratem Fujiwara no Michinagą (966-1028). Zwycięża Michinaga, który ponadto przyczynia się do zesłania Korechiki na południe wyspy Kyūshū. Główną podejrzaną o współpracę z Michinagą była Sei Shōnagon. Od tej pory niesłusznie posądzona o zdradę pisarka musiała znosić wzgardę okazywaną jej przez inne damy dworu. Smutną atmosferę na dworze pogrążyła wieść o uczynieniu córki Michinagi - Shōshi, drugą oficjalną żoną cesarza Ichijō. Po raz pierwszy w historii dworu Heian cesarz miał u swego boku dwie żony o równorzędnym statusie. $\mathrm{Na}$

odpowiada za odbiór wszystkich nie związanych z językiem dźwięków. Według Tsunody w odróżnieniu od Europejczyków, którzy odbierają odgłosy zwierząt i owadów prawą półkulą, Japończycy przetwarzają te dźwięki półkulą lewą, gdyż podobnie jak język, w ich odczuciu dźwięk owadów jest nośnikiem konkretnych znaczeń. Specyficzna recepcja dźwięku ma odzwierciedlenie w języku japońskim, w którym dominują samogłoski, a ich melodyjność utożsamia się z odgłosami przyrody. Z tego powodu Japończycy szybciej niż przedstawiciele Zachodu potrafią wychwycić naturalne, nieharmoniczne dźwięki i nawet czerpać z ich słuchania przyjemność. W efekcie muzyka stworzona przez Japończyków bardzo różni się od muzyki Zachodu. Jest to również uzasadnienie występowania tak wielu wyrazów onomatopeicznych w języku japońskim oraz stosowania licznych efektów dźwiękowych w produkcjach filmowych. Dzieje się tak dlatego, że w odczuciu Japończyków, każdy z tych dźwięków jest nośnikiem jakiejś intencji i posiada konkretne znaczenie. Lewa półkula mózgu Japończyków odpowiada ponadto za ludzkie odgłosy emocjonalne oraz dźwięki japońskich instrumentów. Muzyczna półkula prawa specjalizuje się w przetwarzaniu dźwięków mechanicznych i harmonicznych jak zachodnie instrumenty muzyczne. Według Tsunody fakt, że u Japończyków lewa storna mózgu pełni funkcje logiczne i emocjonalne może tłumaczyć powstanie unikalnej kultury japońskiej, w której jedność umysłu i emocji stanowi wspólną cechę wielu dziedzin rodzimej twórczości artystycznej. Zob. T. Tsunoda, The Japanese brain: uniqueness and universality, Tokio 1985.

12 Waka - japońska pieśń, rodzaj klasycznej poezji japońskiej; obejmuje m.in takie gatunki, jak: chōka (pieśń długa), tanka (pieśń krótka), katauta (pieśń cząstkowa). 
dworze nowej cesarzowej Shōshi służyła rywalka Sei Shōnagon - Murasaki Shikibu. Damy te różniły się od siebie temperamentem, co odzwierciedlały w swojej twórczości. Murasaki, znana z opanowania, taktu i niebywałej erudycji, szczerze nienawidziła Sei Shōnagon - osobę nieprzeciętną, ale odznaczającą się ciętym dowcipem i odwagą w wyrażaniu poglądów. Mimo wzajemnej niechęci obie literatki łączyła fascynacja muzyką, czego dowodziły w swoich utworach.

Opowieść o księciu Genji, choć dotychczas traktowana przez muzykologów jako główne źródło wiedzy na temat japońskiej muzyki dworskiej, w rzeczywistości powinna budzić wątpliwości pod względem wiarygodności. Wprawdzie Murasaki Shikibu zawarła w swym dziele wiele wątków autobiograficznych i przedstawiła w nim - wydawałoby się - realistyczny obraz życia arystokracji dworskiej X wieku ${ }^{13}$, to jednak jest to fikcja literacka. Natomiast Zapiski spod wezgłowia zawierające cechy eseju i pamiętnika zuihitsu, pomimo subiektywnych refleksji i przemyśleń autorki, stanowią wierną relację zdarzeń dziejących się w pałacu i przez to zasługują na miano cennego źródła historycznego. Sei Shōnagon pisze o tańcach bugaku, rozwianych włosach, poruszającej muzyce. Opisuje, jak wyglądały ceremonie buddyjskie i shintoistyczne oraz obchodzone święta. Wszystko to daje nam konkretny i wiarygodny obraz tego, co działo się w życiu muzyczym na dworze cesarskim i jak wysoką pozycją cieszyła się wówczas muzyka gagaku.

Oprócz konkretnych informacji istotnych dla badaczy historii muzyki tego okresu, odnajdujemy w Zapiskach spod wezgłowia przede wszystkim niezwykły kunszt opisywnia uczuć wywołanych każdą zasłyszaną nutą. Poetycki styl natomiast, jakim posłużyła się Shōnagon do napisania tekstu, pomógł jej przekazać emocje i wyrazić swój stosunek do odbieranej muzyki. Efektem tego jest jeszcze barwniejszy opis, który pozwala nam dużo łatwiej wyobrazić sobie, jaką formę miała jedenastowieczna muzyka japońska i jak wpływała na słuchaczy.

Choć obecnie podważa się zdolności muzyczne Shōnagon, czytając dzieło nie można pozbyć się wrażenia, że autorka obdarzona jest nadprzeciętną wrażliwością muzyczną. Zwraca bowiem uwagę na niekiedy mało słyszalne, niezauważalne dla przeciętnego słuchacza dźwięki, potrafiąc przy tym odnieść się do nich, skrytykować bądź pochlebić, wyjąć esencję każdego pojedynczego dźwięku i oddać ją słowami.

\section{Sposoby przejawiania się muzyczności w Makura no Sōshi}

Muzyczność Makura no sōshi daleko odbiega od problemu muzyczności innych dzieł literackich, szczególnie prozy zachodniej, w której treść, tytuł oraz zastosowany język ściśle nawiązywałyby do określonego dzieła muzycznego, a sama kompozycja tworzona byłaby podług muzycznych reguł. Wiąże się to z japońskim stosunkiem do muzyki w ogóle, a także $\mathrm{z}$ tendencją do wybierania $\mathrm{z}$ wielu dźwięków jednego brzmienia i koncentrowania się na nim, czyli przeciwnie niż w kulturze zachodniej, dla której charakterystyczne jest

\footnotetext{
13 Zob. I. Morris, Świat księcia Promienistego, przeł. T. Szafar, Warszawa 1973.
} 
upodobanie do konkretnej melodii bądź wybranej kompozycji muzycznej. Przykładów tak unikalnego podejścia do muzyki można się doszukać w rozmaitych dziedzinach kultury Japonii, między innymi w tradycyjnej architekturze, której ważnym elementem jest suikinkutsu ('dziupla wodnej cytry') - ornament japońskich ogrodów, w kształcie kamiennej studzienki skonstruowany tak, aby w wyniku uderzenia kropel o wodę wywołać wrażenie dźwięku cytry koto. Zatem to nie harmonia, czyli szereg następujących po sobie współbrzmień, dostarcza emocji Japończykom, ale każdy pojedynczy dźwięk budzący różnorodne skojarzenia i odczucia.

Motegi dowodzi, że Japończykom zasłyszane dźwięki nie wydają się abstrakcją, ponieważ nie tylko odczuwają je oni bardzo emocjonalnie, ale także wizualizują ${ }^{14}$. Wyrażanie uczuć za pomocą opisów muzyki oraz emocjonalne przywiązanie do poszczególnych tonów wypływa z naturalnej tendencji Japończyków do imitowania dźwięków zasłyszanych w przyrodzie i ma bezpośredni związek z tradycją shōga, czyli z mnemotechniczną imitacją melodii granej na instrumencie ${ }^{15}$. Dlatego w przeciwieństwie do niektórych dzieł literatury europejskiej, w których muzyczność polega głównie na tematyzacji dzieła literackiego, jak na przykład w wypadku Sonaty Kreuzerowskiej Lwa Tołstoja, wynikającej z inspiracji twórcy konkretnym utworem muzycznym, albo prozodii formy poetyckiej, Zapiski spod wezgtowia stanowią przejaw fascynacji autorki bogatym życiem muzycznym na dworze w XI-wiecznej Japonii i esencję japońskiej wrażliwości na dźwięki zasłyszane w przyrodzie. W trzytomowym dziele Shōnagon doszukamy się zatem opisów muzycznych i muzyczności na następujących poziomach.

\section{Poziom tematyzowania muzyki} poprzez wprowadzenie opisu świąt, obyczajów dworskich oraz instrumentów
popularnych w okresie Heian

Gdy dotarliśmy do świątyni Shakuzenji, u bramy głównej stali już muzycy morokoshi ${ }^{16}$, prezentując tańce shishimai i komainu ${ }^{17}$. Naraz słychać było dźwięk fletni shō i bębna tsuzumi. Jakąż to krainę buddyjską odwiedził? - zastanawiłam się, czując jak dźwięk muzyki rozbrzmiewa i unosi się wysoko aż do nieba ${ }^{18}$.

14 K. Motegi, op. cit., s. 215.

15 Ibidem, s. 215.

${ }^{16}$ Morokoshi-dawna japońska nazwa Chin.

17 Shishimai (taniec lwa) - tradycyjny taniec pochodzenia chińskiego, wykonywany w Japonii jako część widowiska gigaku (starożytnych przedstawień teatralnych prezentowanych w świątyniach buddyjskich od VII do IX w.). Jeśli chodzi o komainumai (taniec koreańskiego psa), to był to rodzaj tańca pochodzenia koreańskiego, który był wykonywany wraz z shishimai w ramach gigaku.

18 Sei Shōnagon, Makura no sōshi, red. S. Matsuo, K. Nagai, Tokio 1974, s. 390. Wszystkie cytowane w niniejszym artykule fragmenty utworów i opracowań, o ile nie zaznaczono inaczej, są w przekładzie autorki. 
W stosunkowo skromnym objętościowo dziele Makura no sōshi autorka szczególnie dużo miejsca poświęciła opisom dworskich zwyczajów i obchodzonych świąt, akcentując najbarwniejszą ich część - widowiska muzyczne i liczne obrzędy religijne. Z każdym kolejno opisywanym świętem pojawiają się nowe style muzyczne, tańce i śpiewy, towarzyszące uroczystościom i stanowiące największą atrakcję dla żądnych wrażeń dworzan. Najbardziej wyraźnego podziału muzyki Sei Shōnagon dokonała ze względu na jej przynależność do danego obrządku, który z powodu dualizmu religijnego Japonii celebrowany jest w tradycji shintoistycznej albo buddyjskiej. Ceremoniał shintoistyczny obejmuje obrzędy (matsuri), wśród których znajduje się rinji no matsuri (specjalne obrzędy obchodzone tylko w przypadku ważnych wydarzeń w kraju) obchodzone w świątyniach Kasuga-taisha w Narze, Kamigamo-jinja w Heian oraz Iwashimizu Hachimangū w Yawata. Towarzysząca im muzyka shintoistyczna obejmuje: festiwalową muzykę gagaku, wykonywane z jej towarzyszeniem tańce bugaku, tańce i pieśni kagura ${ }^{19}$ oraz muzykę wokalno-instrumentalną azuma asobi ${ }^{20}$. W Zapiskach spod wezgłowia zawarto dokładne opisy kostiumów tancerzy, uchwycono mimikę twarzy wykonawców, cechy pantomimy, a także wiernie oddano atmosferę, w jakiej odbyło się przedstawienie.

W wypadku obrzędów buddyjskich oprócz muzyki gagaku, która prezentowana jest w obu obrządkach, opisano przede wszystkim tańce shishimai i komainu. Wiele miejsca poświęcono także śpiewom sutr buddyjskich shōmyō, melodii dzwonów bonshō czy dźwiękom buddyjskich utensyliów. Do najczęściej przedstawianych ceremonii buddyjskich należą gongyō (ceremonia odprawiania modlitw przed statuetką Buddy) oraz hōe (ceremonie odprawiane w celu głoszenia nauki Buddy), w których autorka wiele uwagi poświęca się zachowaniu kapłanów, objaśnieniu sposobu śpiewania buddyjskich inkantacji i ich sile oddziaływania na zgromadzonych wiernych.

Oprócz muzyki religijnej w Zapiskach spod wezgłowia została przedstawiona muzyka świecka: dworska i ludowa. Pierwsza z nich reprezentowana jest przez rozmaite rozrywki muzyczne pielęgnowane na dworze, jak: lekcje gry na koto, zwyczaj słuchania śpiewu ptaków i owadów, recitale dworskiej orkiestry kameralnej kangen czy koncert na lutni biwa $\mathrm{w}$ wykonaniu cesarzowej Teishi. O muzycznych zainteresowaniach arystokracji dworskiej świadczy również następujący fragment dzieła:

Dwudziestego dnia drugiego miesiąca, w blasku słońca padającego zza bezchmurnego nieba, pod zachodnim okapem komnaty watadono, cesarz zaabsorobowany był lekcją fletu. Ćwiczył go znakomity mistrz - generał Fujiwara no Takatō, starszy asystent gubernatora. W duecie na flet i koto, kilkakrotnie wykonali pieśń Takasago ${ }^{21}$ muzyki saibara. Uroczo wyglądał sam mistrz Takatō, kiedy instruował cesarza jak zagrać poszczególny fragment kompozycji. Gdy zgromadziłyśmy się pod parawanem misu i przyglądałyśmy muzykom, ogarnęło mnie uczucie niespełnienia niczym w pieśni Seritsumishi ${ }^{22}$.

19 Kagura (muzyka bogów, rozrywka bogów) - forma sceniczna obejmująca pieśni, tańce i scenki rodzajowe prezentowane podczas obrzędów shintoistycznych.

${ }^{20}$ Azuma asobi (muzyka ze wschodnich prowincji) - pieśni i tańce japońskie wywodzące się z tradycji shintoistycznej.

${ }_{21}$ Takasago (Zatoka Takasago) - znana pieśń gatunku saibara, śpiewana przez mężczyznę do ukochanej.

22 Sei Shōnagon, Makura no sōshi, s. 376. Seritsumishi (Zbieracz pietruszki) - smutna pieśń o niespełnionych nadziejach, związana z legendą o biednym ogrodniku, który pracował na dworze cesarzowej. Pewnego dnia, podczas służby, zerwała się wichura i porwała przesłony misu w komnacie cesarzowej. Ogrodnik po raz pierwszy ujrzał piękną cesarzową, która spożywała posiłek z ziolonej pietruszki i od razu się zakochał. Niestety 


\section{Bęben tsuri-daiko \\ Kasuga Taisha, Nara, \\ grudzień 2009 \\ (fot. A. Bednarczyk)}

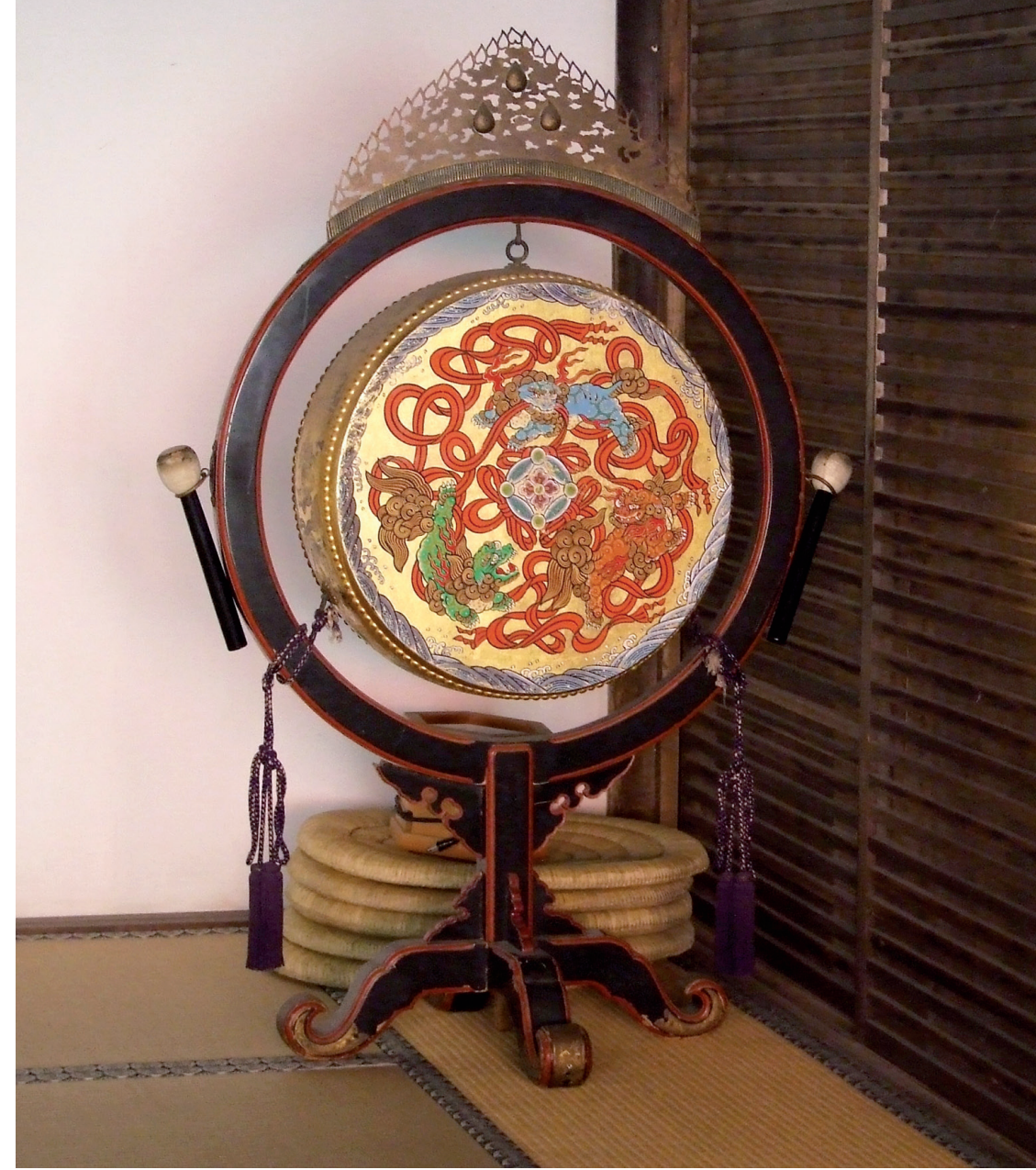

Na uwagę zasługuje również niecodzienny w literaturze Heian fragment poświęcony życiu muzycznemu wieśniaków. Autorka opuszcza mury pałacu i ze zdziwieniem przygląda się wiejskiemu życiu. Jej uwagę przykuwa pieśń ludowa, śpiewana przez wieśniaków podczas sadzeniu ryżu.

W drodze do światyni Kamo widziałam, jak kobiety odziane w okrągłe kapelusze w kształcie misy stały na środku pola i przyśpiewując sadziły ryż. Następnie pochyliły plecy i wpół zgięte wykonywały dziwne ruchy. Co one robią? Nie wiadomo, w jakim celu stopniowo zaczęły się pochylać do tyłu. Ten rzadki widok przyciągnął moją uwagę i sprawił, że zatrzymałam się i przyglądałam zdarzeniu. Wówczas zaczęły śpiewać pieśń obrażającą śpiew kukułki.

Ach ty kukuło, kukuło przeklęta! To przez to, że śpiewasz, musimy teraz harować na polu! ${ }^{23}$

ze względu na niski status społeczny nie dane mu było zobaczyć ją ponownie. Zrozpaczony, pamiętając o ulubionym warzywie cesarzowej, każdego dnia zrywał liście pietruszki i kładł pod jej oknem. Niestety, marzenie o ponownym ujrzeniu cesarzowej nie spełniło się i ogrodnik umarł w samotności.

${ }^{23}$ Sei Shōnagon, Makura no sōshi, s. 380. 
Japończycy od najdawniejszych czasów zwykli kojarzyć nadejście danej pory roku z charakterstycznym dla niej elementem przyrody. Symbolem wczesnej wiosny jest śpiew gajówki (uguisu) ${ }^{24}$. Można się o tym przekonać, czytając najstarsze antologie pieśni japońskich jak Man'yōshū lub Kokinshū, w których motyw gajówki na gałązce śliwy przewija się wielokrotnie, niezależnie od autora poematu. Analogicznie zimie przypisany jest dźwięk przelotnego i drobnego deszczu (shigure - deszcz czasu), natomiast oznaką lata jest wołanie kukułki, zwłaszcza kukułki górskiej (yama hototogisu), gdyż wierzono, że zimą ukrywa się ona w górach. Dziś dobrze znany jest jednak fakt, że kukułki przylatują do Japonii w maju z południowych krajów.

Kukanie kukułki, choć melodyjne, nigdy nie cieszyło się sympatią Japończyków. Szczególnie donośne wczesnym rankiem, budziło wieśniaków, dlatego kojarzono je głównie $\mathrm{z}$ ponagleniem do ciężkiej pracy na roli. W podaniach ludowych natomiast przypisywano mu cechy magiczne. Wierzono, że przenikliwe wołanie kukułki ma moc przywoływania złych duchów i jest zapowiedzią nieszczęścia, stąd należy go unikać.

Przytoczony fragment ukazuje zasadnicze różnice w mentalności arystokracji i ludu okresu Heian. Sei Shōnagon, zachwycona śpiewem kukułki, wyraża pogardę w stosunku do tych, którzy nie potrafią go docenić. Ponadto poprzez rozważania na temat piękna głosu ptaka autorka jakby potwierdza doniosłe znaczenie muzyki przyrody w kulturze japońskiej X-XI wieku.

Tematyzacja muzyki w Zapiskach spod wezgłowia dotyczy nie tylko obrzędów religijnych i zwyczajów dworskich. W utworze tym zawarto również szczegółowe opisy popularnych ówcześnie instrumentów muzycznych, między innymi oboju hichiriki, fletu fue i shakuhachi, organków shō, bębna taiko, cytry koto czy lutni biwa. Poszczególne fragmenty opatrzono notą na temat historii instrumentów oraz powstania ich nazewnictwa. Pojawiają się zabawne anegdoty dotyczące rodowodu instrumentów, a także liryczne opisy uczuć wywołanych ich brzmieniem. Dodatkowo liczne opisy tańców i wzmianki dotyczące pieśni japońskich czynią z utworu ważny dokument historyczny, będący jednocześnie świadectwem zachowania ciągłości tradycji. Zilustrowane w Zapiskach spod wezgłowia taniec batō (dosł. 'odcięta głowa') czy pieśń Takasago (zatoka Takasago) do dziś są kultywowane i stanowią ważny element repertuaru gagaku.

Najciekawsze z pieśni utaimono są pieśni ludowe, które łączą w sobie melodie i obyczaje wielu krajów oraz tradycje wielu narodów. Wśród tego rodzaju pieśni najbardziej radosna jest Sugitaterukado ${ }^{25}$. Istnieje też wiele wspaniałych kompozycji kagura, choć za najlepsze uważa się popularne obecnie ryūkōka $a^{26}$, ponieważ mają długie zwrotki i zmiennę melodię, przez co brzmią bardzo nowatorsko ${ }^{27}$.

\section{Opis dźwięków}

Jedną z głównych cech japońskiej percepcji muzyki jest przywiązanie do ciszy i traktowanie jej jako niezbędnego elementu muzycznego. Cisza tak często rozpatrywana szczególnie w kontekście muzyki dworskiej gagaku i muzyki teatru nō, w której przestrzeń całkowitego

\footnotetext{
${ }^{24}$ Gajówka (Sylvia borin) - ptak wędrowny z rodziny pokrzewkowatych.

${ }_{25}$ Sugitaterukado ('cedrowa brama')

${ }^{26}$ Ryūkōka - popularne pieśni powstałe w okresie Heian i inspirowane muzyką kontynentalną.

27 Sei Shōnagon, Makura no sōshi, s. 413.
} 
wyciszenia dźwięku, oddechu muzyka i zawieszenia melodii określano terminem ma, nie tylko stanowi podstawę rytmu w muzyce japońskiej, ale nadaje jej także niezwykle naturalny charakter odpowiadający nieskrępowanemu pulsowi przyrody. W twórczości zachodniej pauza muzyczna traktowana jest jako przerwa między dźwiękami o różnej długości. W Japonii natomiast cisza jest siedliskiem życia i muzyki. Trudno jednak wykorzystać tę wiedzę do analizy dzieła Sei Shōnagon, w którym autorka nie stroni od opisów dźwięków i muzyki, przez co sam utwór daleki jest od japońskiego umiłowania ciszy ${ }^{28}$.

Na czterystu kartach swojego dzieła Shōnagon wylicza najróżniejsze i zarazem niezwykle trudne do zakwalifikowania dźwięki i głosy, jak między innymi dźwięki zasłyszane podczas ceremonii buddyjskich i shintoistycznych, brzmienia poszczególnych instrumentów, odgłosy przyrody, świst wiatru, opad deszczu, śpiew ptaków, cykad i świerszczy, dźwięki mechaniczne oraz sztuczne jak pisk zamykanych drzwi, szelest jedwabiu itd. Jeden dźwięk przenika drugi, z jednego dźwięku rodzi się kolejny, zmieniejąc swoją barwę i natężenie. Autorka niejako tworzy muzyczne ilustracje i z opisu śpiewu kukułki przechodzi umiejętnie do opisu trzepotu skrzydeł. W utworze pojawiają się ponadto dźwięki powstałe $\mathrm{w}$ wyniku wykonywania jakiejś czynności, dźwięki zasłyszane w oddali i te rozlegające się blisko, dźwięki wywołujące niepokój i przyjemne dla ucha ${ }^{29}$. Wiele z nich przedstawiono obiektywnie, w zgodzie z ogólnym wyobrażeniem, natomiast opisy niektórych dźwięków świadczą o subiektywnej ocenie autorki i jej stosunku do danego brzmienia, odkrywając przy tym buńczuczny charakter, poczucie humoru i skłonność do krytyki Shōnagon.

Cechą szczególną muzyki w Zapiskach spod wezgłowia jest równorzędne traktowanie dźwięków przyrody i dźwięków wydobytych z instrumentów. Świadczy to o unikalnej percepcji muzycznej arystokracji Heian, która do muzyki natury przywiązywała szczególną wagę i słuchała jej na podobieństwo muzyki instrumentalnej. W efekcie tekst wzbogacony jest licznymi porównaniami brzmienia instrumentu do danego aspektu flory i fauny, a poszczególne elementy przyrody nierzadko zestawiane są z instrumentami muzycznymi. Dodatkowo każdy opis koncertu bądź widowiska jest opatrzony dokładną relacją na temat tego, co dzieje się dookoła i jak na koncert reaguje przyroda.

Związek muzyki z przyrodą wyrażany jest również poprzez ogólne przeświadczenie, że każdy występ instrumentalny powinien się odbyć na łonie natury bądź w środowisku, który będzie je przypominał, gdyż tylko wtedy z największą siłą będzie oddziaływał na zmysły widza. $\mathrm{Z}$ tego powodu nawet kameralne recitale mieszkańców dworu oraz lekcje gry na instrumencie odbywały się przy otwartych drzwiach fusuma lub w ogrodzie, otwartej przestrzeni, tak aby muzycy podczas ćwiczeń mogli jednocześnie podziwiać piękno naturalnego krajobrazu.

Zwyczaj świadomej kontemplacji muzyki przyrody - niespotykany w kulturze Zachodu - trwale zapisał się w obyczajowości arystokracji Heian. Świadczy o tym również fragment o tym, jak młode damy wybierały się na spacer, by posłuchać śpiewu kukułki. Zdziwienie czytelnika europejskiego może wywołać również zawarta w Zapiskach spod wezgłowia polemika na temat wyższości głosu kukułki nad śpiewem gajówki. Według Motegi nie jest to jednak jedyny dowód japońskiego umiłowania dźwięków natury. W kulturze japońskiej wszechobecny jest zwyczaj wykorzystania dźwięków przyrody w codziennym życiu. Przykładem są chociażby tradycyjne japońskie ogrody, w których intencjonalnie tworzy się wodospady, wypuszcza świerszcze i cykady. Wszystko po to, aby stworzyć wrażenie naturalnej

28 S. J. Francis Mathy, op. cit., s. 141-142.

${ }^{29}$ K. Motegi, op. cit., s. 222-223. 
orkiestry muzycznej i wprowadzić do otoczenia nowe efekty artystyczne. Dźwięki celowo osadzone są w czasie i przestrzeni ${ }^{30}$. Z Zapisków spod wezgtowia dowiadujemy się, że szum wodospadu, przyrównywany do śpiewu kukułki brzmi jeszcze urokliwej, jeśli słyszany jest w nocy, natomiast smutny dźwięk dzwonu kane, zabrzmi o wiele piękniej spokojnym wieczorem niż w gwarne południe.

Zimą, kiedy w mroźną noc leżysz z ukochanym otulona kołdrą, przyjemnie jest usłyszeć dźwięk świątynnego dzwonu, który rozbrzmiewa jakby z otchłani. Równie dziwnie i głucho brzmi pierwsze szczebiotanie ptaków. Ich dziobki wciąż jeszcze wciśnięte są w skrzydełka. A potem jedna ptaszyna za drugą podnosi głos. Jakże wspaniale jest tak leżeć i nasłuchiwać dźwięku, który staje się coraz wyraźniejszy ${ }^{31}$.

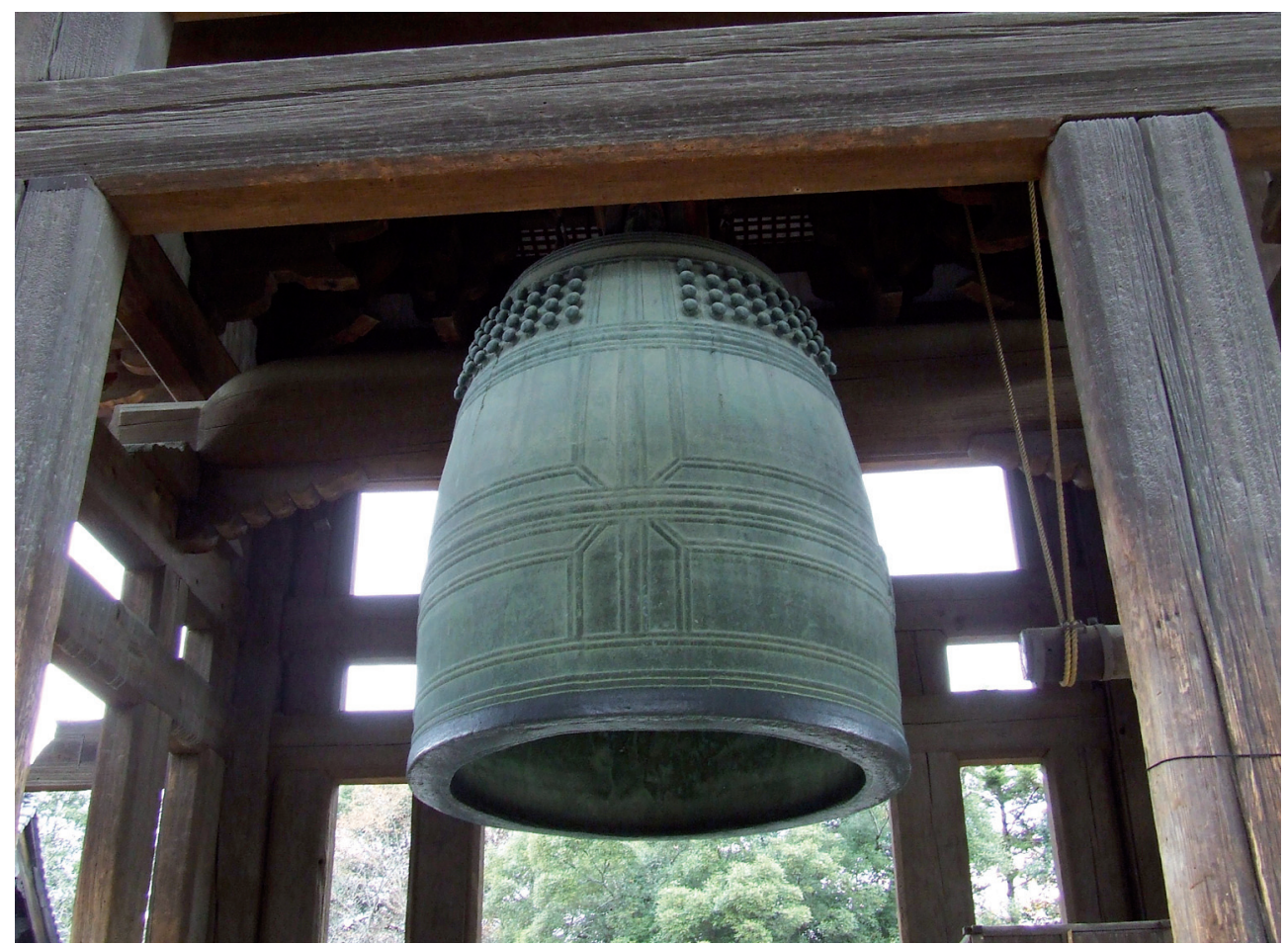

\section{Wizualizacja muzyki}

W Makura no sōshi zastosowano zabieg wizualizacji muzyki, polegający na przedstawieniu zjawisk muzycznych (np. taniec, gra na instrumencie), bez uwzględnienia ich sfery dźwiękowej. Wielu literaturoznawców, z Tetsuo Kuboki na czele, krytykuje dzieło uzasadniając, że pomimo licznych opisów muzycznych zawartych w Zapiskach spod wezgłowia, utwór pozbawiony jest muzyczności. Zainteresowanie autorki koncentruje się nie na dźwięku sa-

\footnotetext{
30 Ibidem, s. 224-225.

31 Sei Shōnagon, op. cit., s. 159.
}

Dzwon w pobliżu pawilonu Nigatsudō, Nara, grudzień 2009

(fot. A. Bednarczyk) 
mym w sobie czy wykonywanej melodii, lecz na mimice twarzy wykonawcy, jego gestach, ogólnej aparycji bądź kostiumie. Shōnagon szczegółowo charakteryzuje instrumenty muzyczne, wyjaśnia nazewnictwo, ilustruje taniec batō i wdzięk muzyków, ale całość wykonania kompozycji muzycznej, jej brzmienie i ocenę pozostawia bez komentarza. Opisy muzykologiczne zawarte $\mathrm{w}$ Zapiskach spod wezgłowia właściwie pozbawione są cech muzycznych, a jedynie poprzez proces tematyzacji dają nam wizualny obraz tego, co działo się w życiu muzycznym okresu Heian. Niczym fotografie wpływają na naszą wyobraźnię, ale nie oddziałują na zmysły, niosąc ze sobą jedynie informacje teoretyczne bądź historyczne ${ }^{32}$.

Trudno jest, moim zdaniem, w pełni zgodzić się z Kuboki Tetsuo i zarzucić autorce brak wiedzy i wrażliwości muzycznej, a w konsekwencji umiejętności oddania muzyki słowami. W wielu wypadkach szczegółowe deskrypcje dźwięków lub melodii są zbędne, ponieważ już samo wymienienie nazwy określonego instrumentu bądź pieśni wywołuje w czytelniku - zwłaszcza japońskim - pewne desygnaty dźwiękowe (konotacje muzyczne) i bez trudu jest on w stanie sobie wyobrazić, jak dany instrument mógł brzmieć.

Wizualizacja muzyki przejawia się tutaj w jeszcze innym aspekcie. Opisy instrumentów muzycznych, pantomimy czy koncertu nie zawsze mają na celu wywoływanie wrażenia muzyczności, lecz podkreślić ich walory estetyczne, wizualne bądź symboliczne. Przykładem może być zilustrowanie tańca gosechi przez opis strojów, uroku młodych tancerek, ich gestów i gracji, z jaką się poruszają oraz deskrypcje instrumentów, zwłaszcza fletni shō. Z Zapisków spod wezgtowia dowiadujemy się, że instrumenty w okresie Heian ceniono nie tylko ze względów brzmieniowych, muzycznych, lecz także jako przedmioty piękne i szlachetne, a nawet obiekty sztuki, które same w sobie posiadały szczególną wartość estetyczną. Przedstawienie ich zatem miało na celu nadanie tekstowi dodatkowych walorów estetycznych, swoistej poetyckości, wzniosłości, a także ukazanie eleganckiego, wyrafinowanego życia dworzan, uwielbiających otaczać się cennymi przedmiotami. Muzyka wydobywająca się z instrumentów wpływała na ludzkie emocje, dlatego instrumentom przypisywano magiczność. Wierzono, że posiadają duszę, stąd poświęcone im opisy wprowadzały do tekstu element mistyki i tajemniczości.

Swoistej wizualacji możemy się doszukać również w opisach dźwięków. Dotyczy to szczególnie fragmentów poświęconych dźwiękom zasłyszanym w przyrodzie, w których przedmiotem deskrypcji jest nie tylko sam dźwięk, lecz także cały proces jego powstawania oraz otoczenie, w którym się narodził. Efektem takiego zabiegu jest możliwość odbioru tekstu wszystkimi zmysłami, dźwięk zaś staje się nie tylko słyszalny, ale wręcz namacalny, pozbawiony jest swojej abstrakcyjności, ponieważ wyzwala w wyobraźni czytelnika pewne materialne desygnaty, jak kolor, zapach, smak.

Organki shō. Te - najprzyjemniej słuchać w świetle księżyca, gdy z wnętrza powozu dobiegnie ich głos. Trudno rozpoznać grajka, przeszkadza zasłona. Myślisz więc, kto to? I jak wygląda twarz człowieka, który tak gra? Z fletem poprzecznym rzecz się ma podobnie - zręczność jest ważna ${ }^{33}$.

Flet poprzeczny yokobue niezwykle jest piękny. Kiedy dźwięk jego, najpierw dochodząc z oddali, brzmi coraz bliżej, by znowu odplynąć. To śliczne. Myślisz, że już jest blisko, a w tej samej chwili zaczyna się oddalać. Słychać bardzo daleko, coraz bardziej nikły - stajesz w zachwyceniu ${ }^{34}$.

32 T. Kuboki, Sei Shōnagon wa koto ga hikenakatta, "Kokubungaku: gengo to bungei” 1960, vol. 5, s. 18-19.

${ }_{33}$ Sei Shōnagon, Makura no sōshi, tłum. A. Żuławska-Umeda, [w:] Estetyka japońska. Antologia, t. 1, red. K. Wilkoszewska, Kraków 2001, s. 19.

${ }^{34}$ Ibidem. 


\section{Muzyczność na poziomie emocjonalnym}

Obój hichiriki zbyt jest hałaśliwy. Wśród jesiennych owadów znajdziesz podobnie jazgotliwe świerszcze, kutsuwamushi - te są jeszcze gorsze, z bliska nikt nie ma ochoty ich słuchać. Bo złą muzykę najtrudniej wytrzymać. Ale w dniach, w których obchodziliśmy święta dwóch naszych chramów, Kamo i Iwashimizu, zdarzyło się inaczej. Zanim bowiem grajek pojawił się przed najjaśniejszym obliczem Jego Wysokości, gdzieś w cieniu świątyni, próbował swego fletu grając bardzo pięknie. Wtem do muzyki fletu dołącza się obój - to było niezwykłe. Padają westchnienia i pytanie zadane z taką ciekawością, że wydaje ci się, iż włosy dam i książąt, gładko uczesane, nagle zwiną się w loki... I wreszcie, krocząc statecznie w rytm cytry koto oraz fletu fue, pojawili się oni - jakże obaj piękni ${ }^{35}$.

Niewątpliwie główną cechą Makura no sōshi jest subiektywna ekspresja autorki w wyrażaniu silnych doznań i emocji wywołanych zasłyszną muzyką. W zastosowaniu intersemiotycznego zabiegu, polegającego na próbie wyrażenia słowami uczuć zaklętych w muzyce, pomogła autorce kompozycja dzieła, opierająca się częściowo na wyliczaniu zjawisk, wywołujących w niej określone bodźce emocjonalne. Shōnagon wymienia przykładowo zjawiska, które ją wzruszają, przerażają, wprowadzają w dobry lub zły nastrój. Z tekstu dowiadujemy się, że wśród najbardziej nieprzyjemnych rzeczy dla autorki na pierwszym miejscu znajduje się trzepot skrzydeł komara, zwłaszcza kiedy przylatuje do niej w nocy i zawodzi tak głośno, że kobieta dostaje dreszczy. Natomiast gdy słyszy dźwięk fletu, czuje w sercu nieopisaną błogość. Z kolei z niechęcią odnosi się do dźwięku oboju hichiriki, zwłaszcza gdy gra na nim niedoświadczony muzyk, wtedy przerażenie sięga zenitu i włosy stają dęba. Emocjonalność dzieła wypływa także $\mathrm{z}$ fragmentów poświęconych fizycznym skutkom muzycznych wrażeń, jak popsuta fryzura wywołana świdrującym dźwiękiem hichiriki czy pustka i smutek w pałacu, spowodowany gorzkim zawodzniem gajówki. W opisach tych ujawnia się ponadto bystry dowcip autorki, potrafiącej odnieść się i wyrazić słowami każde nawet najtrudniejsze do opisania odczucie. Ładunek emocjonalny w stosunku do usłyszanych dźwięków dodatkowo wyrażany jest przez tak zwane „literackie gesty muzyczne”, czyli wyrazy nacechowane silnie uczuciowo, takie jak: ach, ileż, ależ (nanto, ikani). Sposób odbioru muzyki jest ponadto niezwykle subiektywny i często wynika z indywidualnych doświadczeń bądź emocjonalnego przywiązania autorki do danego głosu. Niekiedy Shōnagon, nie potrafiąc wyrazić własnymi słowami głosu danego zwierzęcia, posiłkuje się wyrażeniami zasłyszanymi w przeszłosci bądź utartymi wyrazami onomatopeicznymi, jak na przykład kowai kowai odnoszącymi się do śpiewu wrony, które autorka zapamiętała z piosenki z dzieciństwa ${ }^{36}$, pomimo że powszechnie używaną onomatopeją na określenie głosu ptaka jest - ka ka.

\section{Poziom symboliczny}

Czy jedziesz powozem, czy wędrujesz piechotą, czy konno - flet zawsze i wszędzie schować możesz za pazuchę, nie widać go wcale - dlatego wśród instrumentów nie znajdziesz lepszego. Cóż dopiero, gdy usłyszysz znajomą melodię - wielka to radość. A jeszcze większą czujesz, kie-

\footnotetext{
35 Ibidem.

${ }^{36}$ K. Motegi, op. cit., s. 224-225.
} 
dy u poduszki znajdziesz flet bardzo piękny, który ktoś odchodząc świtem ... zostawił. Przysyła umyślnego, a ty uroczyście podajesz zgubę w rulonie papieru. Jak urzędowy list ${ }^{37}$.

Czytając Zapiski spod wezgłowia łatwo zauważyć, że autorka nadała pewnym muzycznym elementom swoistych cech symboliczności. Szczególnie wyraźnie zaznacza się to w opisie instrumentów i muzyki, która pojawia się w kontekście miłosnym, wpływając na atmosferę uczuć i relację dwojga kochanków. Za każdym razem, kiedy wczytamy się w tekst, nie możemy się pozbyć wrażenia, że to muzyka przyrody nadaje sytuacji jakiś konkretny kształt, sens, że to ona ma wpływ na jego przebieg. Dźwięk dzwonu buddyjskiego w mroźną księżycową noc czy pianie koguta przedstawiane są jako symbol rozłąki i tym samym nadejścia nowego dnia. $Z$ rozmarzeniem opisuje Sei flet poprzeczny nie tylko ze względu na jego dźwięk subtelny i z łatwością zmieniający natężenie, ale przede wszystkim dlatego, że ten maleńki w rozmiarze instrument przywołuje jej na myśl noc spędzoną z ukochanym. Pisze: jakże zabawnie jest, gdy rankiem znajduje się flet ukochanego pod poduszką, który ten zapomniał poprzedniej nocy. Wówczas wystarczy owinąć go w papier i wysłać kochankowi, a instrument ze względu na skromne rozmiary niczym nie będzie się różnił od miłosnego listu. Instrument jest tutaj zatem symbolem miłości i narzędziem przypomnienia kochankowi o wspólnie spędzonej nocy. Dźwięk deszczu i szum wiatru natomiast są jednoznacznie kojarzone z tęsknotą i wyczekiwaniem kobiety na przyjście ukochanego.

\section{Poziom językowy}

$\mathrm{Na}$ tym poziomie wykorzystano cechy leksyki języka japońskiego, obfitującego w wyrażenia onomatopeiczne, które w sposób bezpośredni imitują zasłyszany dźwięk, ruch bądź wrażenie dotyku. W języku japońskim wyrażenia te dzielone są na dwie kategorie giongo - naśladujące głosy i dźwięki oraz gitaigo - imitujące ruch bądź stan ludzkich emocji. Obecność tych wyrazów w języku, niewątpliwie w dużej mierze ułatwiło autorce przekazanie czytelnikowi dźwięków trudnych do wyrażenia słowami, jak naśladowanie śpiewu kukułki, miałczenie kota, szelest liści czy dźwięk padających kropel deszczu. Ponadto częstotliwość ich występowania w języku japońskich i tym samym wprowadzenie wyrażeń do tekstu wpłynęło na jego umuzycznienie. Fakt zaś, że liczba opisów dźwięków przyrody nie tylko przeważa nad opisami muzyki orkiestrowej, lecz także są one dodatkowo bardziej szczegółowe i treściwe, świadczy o tym, że łatwiej było autorce je wyrazić dzięki pomocy naturalnej instrumentacji głoskowej języka japońskiego. W Zapiskach spod wezgłowia wykorzystano ponadto homofonię niektórych wyrazów, powstałą na skutek skojarzeń autorki danego brzmienia z akcją. Przykładem jest tutaj opis dźwięku wydawanego przez motyla koszykówki (jap. minomushi), który autorka określa jako chichi yo chichi yo, mającego to samo brzmienie co wyraz chichi (ojciec) ${ }^{38}$. Sei bawi się zatem melodią języka ojczystego, podkreślając jego muzyczne cechy. Głos motyla brzmiał bowiem niczym utęsknione wołanie ojca, który wyszedł z domu i nie powrócil. Autorka nie jest jednak w tym względzie pionierką. Tendencja do słyszenia śpiewu ptaków czy bzyczenia owada na podobieństwo słów używa-

37 Sei Shōnagon, Makura no sōshi, tłum. A. Żuławska-Umeda, s. 20.

${ }^{38}$ K. Motegi, op. cit., s. 224-225. 
nych w codzienny języku znana jest w kulturze japońskiej od dawna i określana terminem kikinashi (naśladowanie rzeczy usłyszanej od kiku - słyszeć, nasu, minasu - naśladować). Przykładem może być śpiew kukułki określany jako teppen kaketaka (teppen - szczyt, kakeru - zawiesić), czy bażanta chotto koi chotto koi (podejdź na chwilę) ${ }^{39}$.

\section{Podsumowanie}

Przedstawione w niniejszym artykule omówienie opisów muzycznych występujących w dziele Makura no sōshi Sei Shōnagon miało na celu ukazanie wieloaspektowości tematyki muzyki w literaturze japońskiej XI wieku. Muzyka jako sztuka pełniła w społeczeństwie arystokratycznym okresu Heian ważne miejsce, wywierając przemożny wpływ na tematykę i kompozycję powstałej w tym czasie literatury. Przyczyn tego zjawiska można się doszukać zarówno w historycznych przemianach kraju, kumulacji kontynentalnych form muzycznych i instrumentów w czasach Heian, próby dopasowania ich do warunków japońskich, jak i we wzmożonym zainteresowaniu sztuką arystokracji dworskiej rodu Fujiwara, która ze względu na relatywny spokój polityczny, skierowała swoje zainteresowanie ku muzyczno-literackim rozrywkom artystycznym. Istnieje również wiele czynników kulturowych, przejawiających się w japońskiej wrażliwości i afirmacji odgłosów przyrody, traktowaniu ich na równi z muzyką instrumentalną. W grę wchodzą także uwarunkowania leksykalne i swoista muzyczność samego języka japońskiego, ułatwiająca wyrażanie symboli muzycznych i dźwięków słowami. Przy wszystkich tych aspektach ujawnia się nadprzeciętna wrażliwość muzyczna i wyostrzony słuch Sei Shōnagon, która doskonale potrafiła rozróżnić głosy poszczególnych gatunków owadów i ptaków, nie przechodząc obojętnie obok nawet najbardziej zwyczajnych dźwięków mechanicznych. Głęboka świadomość i wiedza muzyczna wpłynęły zaś na wartość marytoryczną utworu, czyniąc go cennym źródłem historycznym przedstawiającym formy i instrumenty muzyczne, które były popularne na Archipelagu Japońskim w XI wieku. Szczególną uwagę zwracają rozmaite próby wprowadzenia opisów muzyczności do tekstu i tym samym uchwycenia słowami tego, co wymyka się semantycznej definicji. Shōnagon poprzez rozmaite zabiegi literackie, takie jak tematyzacja muzyki, wizualizacja, zabawa eufonią tekstu, a także podkreślanie emocjonalnego wymiaru muzyczności dowiodła, że muzyka i literatura - dwie pozornie wykluczające się dziedziny sztuki, doskonale się dopełniają, tworząc dzieło o wielkiej wartości artystycznej. Zważywszy na pionierski charakter badań interdyscyplinarnych, poświęconych związkom tak odległych od siebie dziedzin sztuki oraz na stosunkowo wczesny okres powstania Zapisków spod wezgłowia, utwór z pewnością zasługuje na uwagę muzykologów i literaturoznawców, a jeszcze wnikliwsze studia nad klasyczną literaturą japońską mogą rzucić nowe światło zarówno w badaniach muzyki japońskiej XI wieku, jak i w zakresie komparatystyki intertekstualnej studiów literaturoznawczych. 